\title{
Between New Virus and News Virus (A Contradictive Situation in Covid-19 Pandemic)
}

\author{
Wildana Wargadinata ${ }^{1, *}$, Iffat Maimunah ${ }^{2}$ \\ ${ }^{1,2}$ Universitas Islam Negeri Maulana Malik Ibrahim Malang, Indonesia \\ "Corresponding author. Email: wildana@bsa.uin-malang.ac.id
}

\begin{abstract}
The study was aimed to investigate the audience's reception of hoax news about Coronavirus-19 (COVID-19) that spread in Indonesian the media (between April and June 2020) and the news impacts on society when dealing with COVID-19 pandemic. This research employed a descriptive qualitative study using a receptive analysis approach. The results showed that public reception of hoax news related to COVID-19 led to an active, constructive meaning of news encoding-decoding with meaning that tended to be of negotiation to adapt to their situation. In addition, the study also discovered that the tendency of opposition in decoding the news led the participants to reject the hoax news of COVID19 altogether. Thus, hoax news related to COVID-19 did not significantly affect the audiences' perceptions, but the news even positively strengthens the audiences' attitude against the news itself. Indonesian audiences as described in this study are not easily led to the media's propaganda, but they are academically-capable to respond and filter information about COVID-19 in the media.
\end{abstract}

Keywords: COVID 19, pandemic, a new virus, infodemic, news virus, the media, reception

\section{INTRODUCTION}

The media is the source of both enlightening and misleading information. The World Health Organization (WHO) stated that the novel coronavirus (COVID-19 virus) has spread all over the world [1] and Indonesia has becomes one of the most-affected countries [2] [3]. The media have carried out the duties [4] to broadcast public health emergencies during COVID-19 epidemic. However, the health information in the media is sometimes inaccurate as there are a lot of misleading news circulated [5]. The Indonesian Ministry of Communication and Informatics, through the AIS Team of the Directorate General of Aptika, until May 5, 2020, has detected 1,401 hoax contents spread through digital platforms (kominfo.go.id, 2020). The infodemic (overabundance of both accurate and inaccurate information/news on pandemic that significantly impede people in finding trustworthy news) adds the challenges which society face during the pandemic [6], threatens public health [7], and becomes another virus for its readers. As a result, people become more depressed, stressed, and panicked [8] and cause big worry [9]. WHO stated that infodemic spreads quickly through social the media and potentially becomes more dangerous virus than the COVID-19 virus itself [10] [11].

People tend to access information about COVID-19 virus via the media [12]. Studies of the media as a source of information and knowledge of COVID-19 virus have reported three main findings. First, the media, as a source of news and information about the pandemic, have been widely exposed to the public [13]. Second, the media have an excellent opportunity to directly communicate health information regarding COVID-19 to the public [14]. Third, the media is an essential tool that to increase public awareness against COVID-19 virus [10]. These findings indicate that the media, as a news source, plays a big role in showing people that COVID-19 is a global issue to deal with collectively.

However, massive amount of news spread in the media has caused the public to be confused and anxious. Unknowingly, the media have presented much information that creates a negative stigma associated with COVID-19 virus. Examples of negative stigma attached to COVID-19 include labellingCOVID-19 as China virus [15], hazardous virus which threatens the safety of the world [9] [16], and a deadly virus [17], 
labeling COVID-19 patients and even cornering COVID-19 patients and their family [18].

The purpose of this paper is to fill in the gaps in the existing studies which position the media as a source of information needed by society. This research focused on the public reception of hoax, confusing, invalid, and even misleading news. It is essential to understand the public reception regarding the context of COVID-19 virus hoax news because the media has played an increasingly important role since the announcement of COVID-19 as a global pandemic by the WHO [9] and the growing significance of access to the media during pandemic. The research problem investigated were formulated as follows: (a) how does the media present COVID-19 hoax news? (b) what is the public reception of COVID-19 hoax news?; and (c) does COVID-19 hoax news affect the public?

The widespread of COVID-19 hoax news in the media are motivated by several factors, including human's innate curiosity, modern communication technology, and confirmation bias. The media in Indonesia can significantly influence the public who follow and trust the media to disseminate information and to persuade them to fight COVID-19 pandemic. The public may follow recommendations given in the media. The current study employed a different argument, that people's literacy and cultural awareness may influence them to avoid reading news since it may cause a new virus that plagues and afflicts the community.

People use the media as the source of information and knowledge. People can choose from a vast selection of the media which provide abundant information. There are at least three trends in the media. First is the effect of the media, in which the media, as a source of information) influence society. Second is that infodemic (confusing news of COVID-19 pandemic which circulates widely) increases people's anxiety and it eventually becomes a new burden heavier than COVID-19 virus itself, third is the audience reception of the media, where people show a sense of maturity in reading/viewing news in the media.

\subsection{The media effect}

People access the media to get information and news quickly [19] [20]. Mitchell et al. [21] mentioned that construction of news in the media plays the most crucial part in influencing their readers' views on certain issues [22] [23]. As a result, the media reality may replace social reality [24]. Since the media can reach wider audiences [20], the media have the power to change audiences' viewpoints [25] [26] [20], either influencing positively by providing evidence-based information to the public [27] or negatively by presenting fake news (hoaxes) and acting against the government's programs [28] by spreading unreliable rumors [27]. Hoax news is perilous [29] and it causes significant negative social effects [30] because it is aimed to deceive and create misunderstanding among readers [31].

\subsection{Infodemic (false news on virus) on the media}

A huge number of information and infodemic news about COVID-19 pandemic has been published and shared on social the media and social networking sites between March and June 2020 [32] [33]. Briand, cited in [27] suggested that the virus outbreak will be accompanied by misinformation and disturbing. The media repeat and perpetuate inaccurate news which eventually threatens the public health and harms people [34]. Hoax news also creates fear, confusion, negative stigma, and makes those who are vulnerable, take actions that are not based scientifically strong evidence [35], in addition to affecting mental health and community welfare [32] [13]. Dr. Ghebreyesus (Director General of WHO), stated that during a pandemic, people fight against the epidemic and infodemics [34], in line with Andrew Pattison (WHO manager of digital business solutions manager,) who asserts that infodemics spread faster than viruses [33] due to the media exposure [36]. Therefore, the alarming spread of infodemics becomes a big problem to overcome. The most important thing to do during the virus outbreak is to ensure people do the correct things to control the disease and reduce its effects. In other words, the focus in not only to ensure people are well informed, but also to ensure people can act appropriately [27].

\subsection{Audiences' Reception of The media}

Understanding a news story requires psychological and cognitive readiness [37]. People with better verbal skills and understanding will understand the encoding concept and get ready to change their situations and emotions accordingly [38]. The media plays a vital role in the universal socialization process, which develops a person's perceptions, thoughts, and behavior [39], especially when the person gains personal awareness of his/her culture and social order. The invasion of news in the media is a great challenge for the public. The media has freedom in presenting great variety and volume of information which allows Readers can choose news according to their interest [40]. Thus, it is crucial to explore how the media represent reality in order to understand how meaning is determined [41]. The audience must realize that reality conveyed by the media is not reality as it is, but an edited, framed reality to better suit the media's ideology, goals, and interests [42] [41] [43]. 
The process of reading news is determined by the audience's reception of the news [41] [44]. The media audiences may have different responses to the media messages due to the audiences' factors, including social position, gender, age, ethnicity, occupation, experience, beliefs, and ability to receive notifications [45] [46] [47]. Thus, news reading process may have various effects on the audiences. Hall [41] mentioned three ways of decoding, interpreting, and reading the media. First is dominant-hegemonic position; it is a condition in which an audience completely accepts the meaning of a message and fully follows the sender's dominant value expressed in the media's preferred reading. Second is negotiated position, in which an audience mostly understands what is defined and signaled in the news; the audience may agree with parts of the news and disagree with other parts. The third one is oppositional position, which is audience receives a code or message, but he/she reshapes it with an alternative code. In an extreme form, groups of audiences may have different views and may immediately reject the viewpoint of the message. The audience disagrees with the dominant value expressed in the media's "preferred reading".

\section{METHOD}

This study aimed to investigate the audience's reception of COVID-19 hoax news reported in the media. This research employed a descriptive qualitative study using Hall's reception analysis approach. Bogdan and Taylor in Moleong [48] stated that a qualitative descriptive researcher collects written or spoken descriptive data from people's observable behaviors. Meanwhile, the reception analysis approach views news audience as the producer of meaning. Using Hall's encoding-decoding theory, the authors intended to explain the process of encoding information contained in the media. Reception analysis was employed to understand the text in the media by understanding how news producers and consumers respond texts differently. The media producers can encode specific messages rooted in their understanding and social context (encoding). When these texts are read, the decoding process takes place, and meanings are created through the news audience's experience.

The data were collected through observation, interviews, and documentation techniques. The authors observed and documented news published in four online news websites (sindo.com, vivanews.com, okezone.com, and cnnindonesia.com). News documented from these media were used as a news source and utilized as interview materials. In-depth interviews were conducted to examine the audience's reception of hoax news related to COVID-19 pandemic. The data were analyzed through three processes, namely (1) restatement of interview data, which became the materials of reception of (encoding and decoding) hoax news related to COVID-19, and classification of data based on the interpretation of Hall's encoding-decoding theory, (2) description process to determine the data patterns and trends, and (3) interpretation process to understand the meaning contained in a statement. The data which have been thematically reduced were displayed in the forms of images, interview excerpts, and related photos. In the final stage, the authors verified the data to understand the data deeply and comprehensively.

\section{FINDINGS}

The mass media have become a trusted source of information since the spread of COVID-19 virus in Indonesia. COVID-19-related news has circulated massively in the media since March 2020. The media published very diverse news, including news on the global growth of COVID-19 virus, the increasing number of COVID-19 patients in Indonesia and globally, prevention, cure, and treatment of COVID-19. The media published news related to COVID-19 so that people can understand well information about COVID19. Observation on news in these the media also indicated the emergence of hoax news related to COVID-19 pandemic, particularly news regarding irrational treatment and care of COVID-19 patients. Much of the published news was not supported by valid data, but people used the news as a guide. The amount of hoaxes related to COVID-19 is huge and it keeps growing

(Kompas.id) .https://bebas.kompas.id/baca/riset/2020/05/12/publikjenuh-pemberitaan-COVID-19/.

\subsection{Hoax News about COVID 19 Virus in the media}

The spread of hoax news about COVID-19 potentially hurt the public and cause panic, confusion, depression, and stress among people. These negative effects emerge because news was published without first verifying the validity and accuracy of the data. Following are examples of news about COVID-19 pandemic published in the media: 
Table 1. Hoax News about COVID 19 Virus in the media

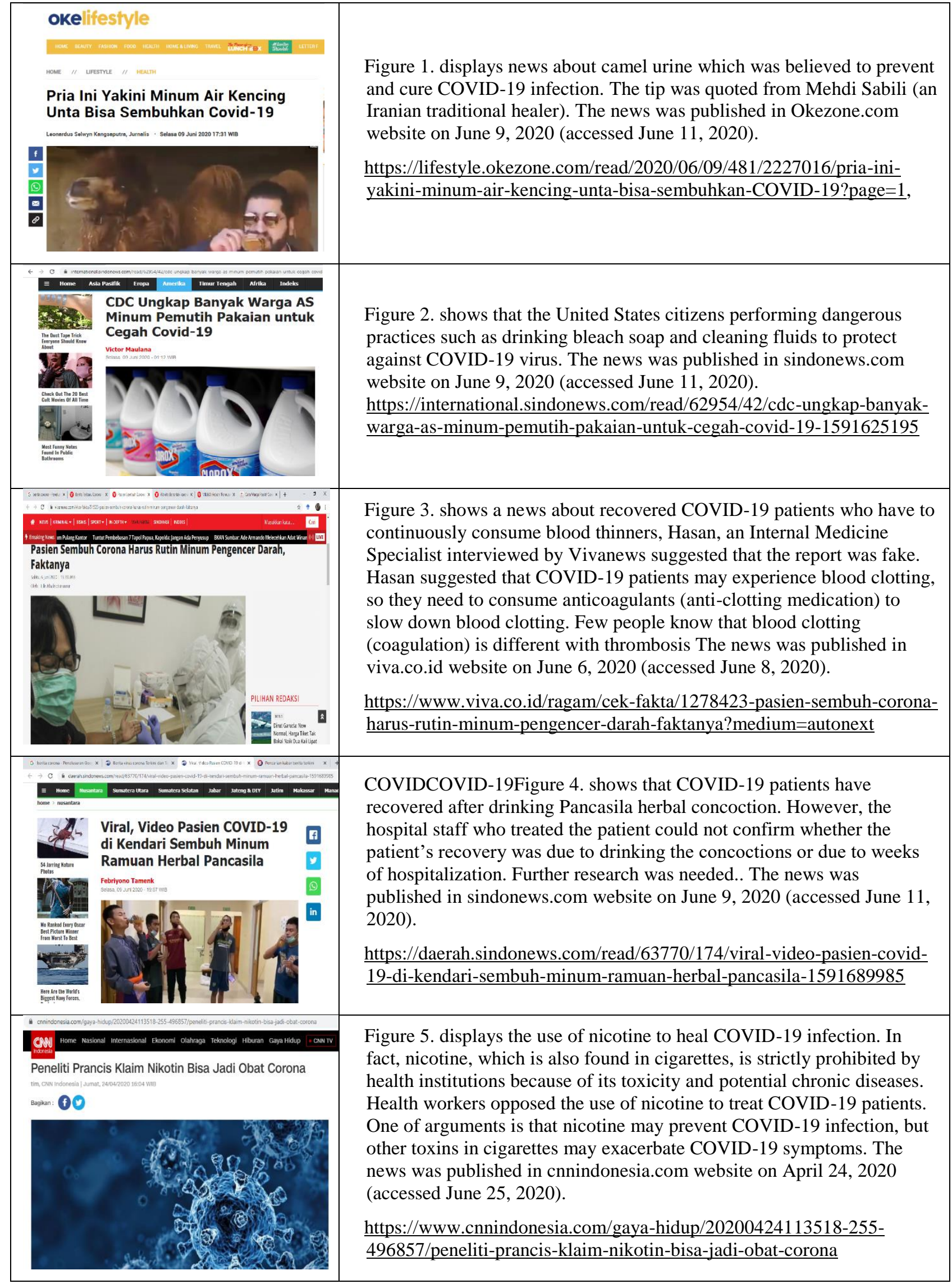


The news in table 1 is categorized as hoax news. The tips shared in the news are not suitable for public consumption because these tips have not been scientifically tested to be used to cure COVID-19 infection. To date, the cure of COVID-19 infection has not been found yet. Meanwhile, the most frequently cited reason for the COVID-19 patients' recovery was the treatment provided by the medical team and the health service center. The medical service and the hospital care of COVID-19 patients were swift, and effective. It also follows the government and WHO's health protocols.

\subsection{Public Reception of Hoax News About COVID-19}

The large amount of news of COVID-19 pandemic causes inevitable diverse public reception. The current study found that the audience's reception of hoax news brought up several statements as an understanding and reading of the circulating information. The audiences' statements of reception (based on the audiences' gender, educational background and occupation, and their reasons) caused the emergence of meaning categories, as shown in the Table 2.

Table 2. Public Receptiooax News About COVID-19

\begin{tabular}{|c|c|c|c|c|c|}
\hline Initials & Gender & Background & Statement & Reason & Type of meaning \\
\hline An & Female & Housewife & Just live normally. & $\begin{array}{l}\text { (Getting tired) of } \\
\text { reading hoax news. }\end{array}$ & Oppositional position. \\
\hline $\mathrm{Ba}$ & Female & Entrepreneur & $\begin{array}{l}\text { (I do) not follow the } \\
\text { circulating hoax } \\
\text { news is better. }\end{array}$ & $\begin{array}{l}\text { Hoax news is exhausting } \\
\text { and dangerous to one's } \\
\text { mind. }\end{array}$ & Oppositional position \\
\hline $\mathrm{Ma}$ & Female & Lecture & $\begin{array}{l}\text { I am disappointed } \\
\text { with the circulating } \\
\text { news. }\end{array}$ & $\begin{array}{l}\text { The (hoax) news doesn't } \\
\text { make any sense. }\end{array}$ & Oppositional position \\
\hline $\mathrm{Li}$ & Female & Housewife & $\begin{array}{l}\text { COVID-19 news is } \\
\text { not everyday news. }\end{array}$ & Misguided news. & Oppositional position \\
\hline An & Female & Teacher & $\begin{array}{l}\text { Just ignore the hoax } \\
\text { news. }\end{array}$ & $\begin{array}{l}\text { The media pretended to } \\
\text { understand. }\end{array}$ & Oppositional position \\
\hline $\bar{A}$ & Female & Housewife & $\begin{array}{l}\text { Just calm down and } \\
\text { disregard the news. }\end{array}$ & $\begin{array}{l}\text { (that is) a scary story, (it } \\
\text { is) to create a bombastic } \\
\text { viral news. }\end{array}$ & Oppositional position \\
\hline $\mathrm{Ag}$ & Male & Army & $\begin{array}{l}\text { We recommend } \\
\text { filtering (and } \\
\text { selecting) accurate } \\
\text { news to read. }\end{array}$ & $\begin{array}{l}\text { Sometimes the media } \\
\text { likes to experiment } \\
\text { (casually). }\end{array}$ & Negotiated position \\
\hline $\mathrm{Bh}$ & Male & Entrepreneur & $\begin{array}{l}\text { It's okay to try and } \\
\text { follow the } \\
\text { suggestions in the } \\
\text { media. }\end{array}$ & There may be a point. & Negotiated position \\
\hline $\mathrm{Sg}$ & Male & Lecture & $\begin{array}{l}\text { Just ignore it (the } \\
\text { hoax news). }\end{array}$ & $\begin{array}{l}\text { Search for valid news } \\
\text { and correct solution. }\end{array}$ & Oppositional position \\
\hline Que & Female & Psychiatrist & $\begin{array}{l}\text { No one should } \\
\text { blindly believe it. }\end{array}$ & Lead to misconceptions. & Oppositional position \\
\hline $\mathrm{Fa}$ & Female & Doctor & $\begin{array}{l}\text { The news is not fit } \\
\text { for consumption. }\end{array}$ & $\begin{array}{l}\text { All medical-related } \\
\text { theories are data-based. } \\
\text { An individual person's } \\
\text { case cannot be a } \\
\text { theoretical proof. }\end{array}$ & Oppositional position \\
\hline $\operatorname{Im}$ & Male & Student & $\begin{array}{l}\text { Hoax news only } \\
\text { seeks sensation. }\end{array}$ & $\begin{array}{l}\text { One should review the } \\
\text { validity of news. } \\
\text { published by overly } \\
\text { impulsive (unstable) the } \\
\text { media. }\end{array}$ & Oppositional position \\
\hline
\end{tabular}

Source: Research, 2020 
Each receptive action of news encoded by the media has provided each audience with different understanding due to the following factors:

1. There has been uncertainty among society in the first three months of COVID-19 pandemic in Indonesia. The society could not determine when the pandemic would end. The situation got worse with the spread of hoax news regarding COVID-19. Many feared that reading/viewing COVID-19 hoax news would disrupt their mental conditions and cause panic and depression. Thus, many people avoid hoax news related to COVID-19 to maintain their mental wellbeing during COVID-19 pandemic.

2. Educated members of society did not take the information and news circulating in the media for granted before they understood the scientific evidence, as well as the accuracy of data and their sources. Likewise, these educated society members would not be easily swayed by the media's framing, vision and mission because they knew that COVID19-related news and health information should adhere the WHO's health standards.

3. The digital natives could filter news that is fit for consumption. These generations thought practically because their lives always intersect with the media and inseparable from broadcasting. If the disseminated information and news are beneficial, the process of understanding the news will be carried out continuously. On the other hand, since the accuracy of information and news sources related to COVID19 are very important, the digital natives would avoid news which stands to create contradicting or competing discourse.

\subsection{The Effect of Hoax News on The News Audiences}

The media is the primary source of information in the "living side by side with COVID-19" era. the encodingdecoding processes run in synergy massively. The published news is an essential source of information during COVID-19 pandemic. Apart from the media providers' and companies' rights to publish news related to COVID-19, the news audiences have also involved in giving meaning to the news published in the media. The published hoax news of COVID-19 did not necessarily affect the audiences to follow and believe the news content. For example, the irrational COVID-19 healing procedures reported in okezone.com, sindonews.com, vivanews.com, cnnindonesia.com websites, used sensitive and debatable news titles. The audiences who blindly accepted the news may contract another infodemic hoax news virus.

Representation of the public response to the hoax and misleading news related to COVID-19 pandemic can be seen from several excerpts of interviews below:
"... I am very disappointed with the news circulated in the media, (I feel) sad and (the hoax news) get increasingly unreasonable, it (the spread of hoax news) does not calm down the public, instead it makes situation becomes more unsettling. It negatively influences the community to become mentally stubborn and ultimately distrust the government." (source, interview, Mn, June 11, 2020)

The public's disappointment in hoax news published in the media has become a cause of social restlessness. The confusing and inaccurate news in the media has contributed to the development of distrust of the government's policies. Eventually, many people echoed their criticisms. Despite sensitive and frontal news about COVID-19 in the media, people will consistently remain to face COVID-19 by totally surrendering one selves to Allah SWT, such as shown in the following excerpt.

"...Those horrible news (regarding the virus) should not be published in the media, because there is only one COVID-19 medicine, namely tawakkal (complete surrendering all matters) to Allah. " (source, interview, Rn, June 12, 2020)

Respondents of the current study suggested that the excessive and inaccurate news tends to only benefit the media. The media may use hoax news to lead their audiences and to increase their website traffics, which solely sides with the media.

"... When the media displays excessive and proactive headlines, they do so to promote their interest, which is to increase the media's website traffic." (Source, interview, Qn, June 14, 2020)

Ideally, all health-related news should be based on data and facts, scientific proofs. In addition, news should be informative and transformative because news in the media is the primary key to reconstruct audiences' respective social cultures.

"... COVID-19 is strongly related to human beings' health, so (patients') treatment should not be based on individual's casual manner; it is essential to read medical doctor's information." (source, interview, Fr, June 17, 2020)

Statements on receptive actions towards hoax news have more or less influence on determining public attitudes. Pragmatically, the audiences have become more careful in reading/viewing information in the media, especially news related to COVID-19. It becomes increasingly important for people to only select and read news published by health and medication-related institutions.

\section{DISCUSSION}

The media is expected to be able to act as a neutral institution that delivers honest and factual information to 
the public during COVID-19 pandemic. The media has a responsibility to stimulate social transformation in various dimensions of people's lives [40] [49] as the community should also provide benefits to others and the environment [50]. Therefore, it is crucial to understand the relationship between the structure and ideology of the information published in the media [51]. Apart from managerial and market demands, the facts have shown hoax news related to COVID-19 have presented in both mainstream the media and social the media. The news about camel urine, clothes bleach, blood thinners, nicotine, Pancasila herbal concoctions have indicated that the media in this study intend not only to convey information or to entertain, but they also bring their and sensitive and promotional (propaganda) purposes. In line with Abdullah [52], the media consciously plan propaganda to build significant power in influencing audiences. Besides, during the COVID-19 pandemic, the media are involved in institutional domination (supremacy), which is effective in spreading COVID-19 information. Gramsci $(1971,1977)$ states that the media is a hegemonic institution which operate through content and news ideas combined with production and distribution practices [53] and the public as a public space for the media news.

The public reception of COVID-19 hoax news spread in the media does not affect the audiences' perceptions, but it rather strengthens their tendency to positively deal with COVID-19 pandemic. This is because the Indonesian audiences nowadays are not uninformed. Since the pandemic is a global problem, the public put efforts together to create a conducive situation. The launched literacy movement has stimulated the society to adopt careful culture of reading/viewing news in the media. The media, whose main focus is as a medium for early health communication tool [9], has been optimized and placed as a source of inspiration to lead the society to a more positive image of the media utilization. It is a manifestation of the idea that knowledge is a social construction [54], which is very substantive in the process of externalization, subjectivity, and internalization [55] of the reception of encodingdecoding news in the media. Likewise, the media can simultaneously form diverse public opinions in the social process, which tend to be constructed, a priori, or even cynical [56].

The audiences' diverse tendency in massively searching for information in the media in order to reduce anxiety during the pandemic should be appreciated. In other words, the media must represent an institution that can instill educational values to the public by offering latest and reliable information about COVID-19 [57] and become a means to control global unrest due to the pandemic [58].

\section{CONCLUSION}

This study has discovered several important findings. First, the audience reception of hoax news of COVID-19 raises an active, constructive meaning of news encodingdecoding receptions. The active, constructive meaning is based on the audiences who are academically established and have attained literacy awareness. The public can respond wisely even during the uncertain pandemic situation and the spread of hoax news as a new virus. Second, the media have to be neutral, not just focusing on increasing their website traffics by presenting splashy, misleading news. The media with their rights and capabilities as an educational institution, should endeavor to lead the readers dealing with the pandemic. Third, another important thing to do is to restore the media's function as a source of information and knowledge. The media should provide valid and reliable content and news sources according to society's needs. This study has at least two technical limitations. First, the data collection only covers several months of news reporting at the beginning of COVID-19 pandemic, while the pandemic itself has clearly not ended yet. Secondly, The news audiences' situation is dynamic and the news in the media has always changed rapidly. Therefore, follow-up studies that investigate audiences' reception of news in different segments are necessary to obtain more comprehensive pictures.

\section{REFERENCES}

[1] P. Sun, X. Lu, C. Xu, W. Sun, and B. Pan, "Understanding of COVID-19 based on current evidence," Journal of Medical Virology. 2020.

[2] R. Djalante et al., "Review and analysis of current responses to COVID-19 in Indonesia: Period of January to March 2020,” Prog. Disaster Sci., 2020.

[3] W. Wargadinata, I. Maimunah, E. Dewi, and Z. Rofiq, "Student's Responses on Learning in the Early COVID-19 Pandemic," Tadris J. Kegur. dan Ilmu Tarb., vol. 5, no. 1, pp. 141-153, 2020.

[4] Y. Zhao, S. Cheng, X. Yu, and H. Xu, "Chinese Public Attention to COVID-19 Epidemic: Based on Social Media (Preprint)," J. Med. Internet Res., 2020 .

[5] J. Y. Cuan-Baltazar, M. J. Muñoz-Perez, C. Robledo-Vega, M. F. Pérez-Zepeda, and E. SotoVega, "Misinformation of COVID-19 on the Internet: Infodemiology Study," JMIR Public Heal. Surveill., 2020.

[6] G. Pennycook, J. McPhetres, Y. Zhang, and D. Rand, "Fighting COVID-19 misinformation on social media: Experimental evidence for a scalable accuracy nudge intervention," PsyArXiv [working Pap., 2020. 
[7] P. Bastani and M. A. Bahrami, "COVID-19 Related Misinformation on Social Media: A Qualitative Study from Iran,” J. Med. Internet Res., 2020.

[8] A. R. Ahmad and H. R. Murad, "The Impact of Social Media on Panic During the COVID-19 Pandemic in Iraqi Kurdistan: Online Questionnaire Study,” J. Med. Internet Res., 2020.

[9] Q. Liu et al., "Health Communication Through News Media During the Early Stage of the COVID19 Outbreak in China: Digital Topic Modeling Approach,” J. Med. Internet Res., 2020.

[10] J. Hua and R. Shaw, "Corona virus (Covid-19) 'infodemic' and emerging issues through a data lens: The case of china," Int. J. Environ. Res. Public Health, 2020.

[11] L. Y. Hsu, P. Y. Chia, and S. Vasoo, "A midpoint perspective on the COVID-19 pandemic," Singapore Med. J., 2020.

[12] A. Shahzad, R. Hassan, N. I. Abdullah, A. Hussain, and M. Fareed, "Covid-19 Imoact On E-Commerce Usage: An Empirical Evidence From Malaysian Healthcare Industry," vol. 8, no. 3, pp. 599-609, 2020.

[13] J. Gao et al., "Mental health problems and social media exposure during COVID-19 outbreak," PLoS One, 2020.

[14] A. Abd-Alrazaq, D. Alhuwail, M. Househ, M. Hamdi, and Z. Shah, "Top Concerns of Tweeters During the COVID-19 Pandemic: Infoveillance Study,” J. Med. Internet Res., 2020.

[15] Y. Zheng, E. Goh, and J. Wen, "The effects of misleading media reports about COVID-19 on Chinese tourists' mental health: a perspective article," Anatolia. 2020.

[16] W. Wargadinata, I. Maimunah, S. R. Febriani, and L. Humaira, "Mediated Arabic Language Learning for Arabic Students of Higher Education in COVID19 Situation," Izdihar J. Arab. Lang. Teaching, Linguist. Lit., 2020.

[17] Y. Yang et al., "The deadly coronaviruses: The 2003 SARS pandemic and the 2020 novel coronavirus epidemic in China," Journal of Autoimmunity. 2020.

[18] D. P. Bruns, N. V. Kraguljac, and T. R. Bruns, "COVID-19: Facts, Cultural Considerations, and Risk of Stigmatization,” J. Transcult. Nurs., 2020.

[19] P. D. Bayuong, M. M. Yunus, and A. Suliman, "The use of social media (SM) among pupils in a rural primary school in Sarawak, Malaysia," Humanit. Soc. Sci. Rev., 2019.
[20] A. N. Shukla, "Social Media and Social Awareness," Man. Digit. Earth, vol. 1, no. August, pp. 425-440, 2020.

[21] A. Mitchell, J. Gottfried, M. Barthel, and E. Shearer, "The Modern News Consumer," Pew Res. Cent., 2016.

[22] W. J. Potter, "Conceptualizing Mass Media Effect," J. Commun., 2011.

[23] D. Freyenberger, "Amanda Knox: A Content Analysis of Media Framing in Newspapers Around the World," Electron. Theses Disertastion, 2013.

[24] O. N. Goryacheva and G. S. Kalinina, "The manipulative capacity of mass media," Humanit. Soc. Sci. Rev., 2019.

[25] A. Siregar, "Media Pers Dan Negara: Keluar Dari Hegemoni,” J. IImu Sos. IImu Polit., 2000.

[26] S. A. Hamid, "Pengaruh Media Massa Terhadap Perubahan Sosial Masyarakat," J. Soc. Sci. Humanit., 2016.

[27] J. Zarocostas, "How to fight an infodemic," Lancet (London, England), 2020.

[28] S. Nasrullah and M. Firdouse Rahman Khan, "Examining the impact of social media on the academic performances of saudi students-case study: Prince sattam bin abdul aziz university," Humanit. Soc. Sci. Rev., 2019.

[29] S. S. Othman, L. M. Nayan, L. K. Tiung, and F. Hassan, "Issues and challenges of future newspapers,” Humanit. Soc. Sci. Rev., 2019.

[30] K. Shu and H. Liu, "Detecting Fake News on Social Media," Synth. Lect. Data Min. Knowl. Discov., 2019.

[31] H. Allcott and M. Gentzkow, "Social media and fake news in the 2016 election," Journal of Economic Perspectives. 2017.

[32] A. R. Ahmad, H. R. Murad, and M. R. Gardner, " "The Impact of Social Media on Hyped Panic during the COVID-19 Pandemic: The Iraqi Kurdistan Case'," (Preprint)," JMIR Ment. Heal., 2020.

[33] Z. Thomas, "WHO says fake coronavirus claims causing' infodemic '," BBC News, 2020. .

[34] The Lancet, "COVID-19: fighting panic with information," The Lancet. 2020.

[35] P. Kulkarni, S. Prabhu, S. K. D, and B. Ramraj, "Covid-19-infodemic overtaking pandemic? Time to disseminate facts over fear," Indian J. Community Heal., 2020. 
[36] M. Y. Ni et al., "Mental Health, Risk Factors, and Social Media Use During the COVID-19 Epidemic and Cordon Sanitaire Among the Community and Health Professionals in Wuhan, China: CrossSectional Survey,” JMIR Ment. Heal., 2020.

[37] S. H. Eason, L. F. Goldberg, K. M. Young, M. C. Geist, and L. E. Cutting, "Reader-text interactions: How differential text and question types influence cognitive skills needed for reading comprehension," J. Educ. Psychol., 2012.

[38] S. Schroeder, "What Readers Have and Do: Effects of Students' Verbal Ability and Reading Time Components on Comprehension With and Without Text Availability,” J. Educ. Psychol., 2011.

[39] G. Shamilishvili, "Psychological influence of modern mass media on formation of gender stereotypes,” Econ. Ecol. socium, 2019.

[40] D. McQuail, "News, public opinion and political communication," in McQuail's mass communication theory, 2010.

[41] S. Hall, "Representation: Cultural Represenation and Signifying Practices," in Representation, 2013.

[42] M. Fahmi, I. Abdullah, H. Hasanah, I. Mujahid, and M. Z. Elizabeth, "Media representations of gender: The marginalization of female Muslim scholars in Indonesia,” Journal of Critical Reviews. 2020.

[43] H. Wardle, "Representation. Cultural representations and signifying practices. Edited By Stuart Hall. London, Thousand Oaks and New Delhi: Sage Publications In association with the Open University. 1997. 400 pp. Pb.: £12.95. ISBN 076195432 5.," Soc. Anthropol., 1999.

[44] D. McQuail, Mass communication theory: An introduction, vol. 4, no. 4. 2010.

[45] A. Shaw, "Encoding and decoding affordances: Stuart Hall and interactive media technologies," Media, Cult. Soc., 2017.

[46] H. Bødker, "Stuart Hall's encoding/decoding model and the circulation of journalism in the digital landscape,” Crit. Stud. Media Commun., 2016.
[47] S. Hall, "Encoding/decoding," in Culture, Media, Language: Working Papers in Cultural Studies, 1972-79, 2003.

[48] D. M. A. Lexy J. Moleong, "Metodologi Penelitian Kualitatif(Edisi Revisi),” PT. Remaja Rosda Karya, 2019.

[49] K. Y. Wang, “Invitation to a deity's celebration: How social media influences participation in the activities of chinese folk temples," J. Study Relig. Ideol., 2015.

[50] W. Wargadinata, I. Maimunah, and R. N. Indah, "Eco-religious approach to deforestation by indonesian istighosah community," J. Study Relig. Ideol., 2020.

[51] S. Hall, "Signification, Representation, Ideology: Althusser and the Post-Structuralist Debates," in Stuart Hall Lives: Cultural Studies in an Age of Digital Media, 2018.

[52] I. Abdullah, S. B. Wahyono, and P. D. Persadha, "Audience culture in the reception of text: Black campaigns on online media during Indonesia's 2014 and 2019 presidential elections," Humanit. Soc. Sci. Rev., 2019.

[53] L. Artz, "Encyclopedia of Media and Communication," Ref. Rev., 2014.

[54] A. Heywood, Political Theory An Introduction. 2004.

[55] S. Puji, "Konstruksi Sosial Media Massa," AlBalagh, 2016.

[56] Bungin and Burhan, "Sosiologi Komunikasi: Teori, Paradigma, dan Diskursus Teknologi Komunikasi di Masyarakat,” Kencana Prenada Media Group, 2009.

[57] M. B. T. Sampurno, T. C. Kusumandyoko, and M. A. Islam, "Budaya Media Sosial, Edukasi Masyarakat, dan Pandemi COVID-19," SALAM J. Sos. dan Budaya Syar-i, 2020.

[58] B. Alim Tualeka and B. Bungin, "The Social Construction of Digital Multimedia and the Policy of Mass Media Coverage in the Creation of HyperReality Politics in Indonesia and Malaysia," Soc. Sci., 2020. 